\title{
The Effect of Intrinsic Motivation on Students' Improvement of English Speaking Skill
}

\section{(A Case Study of the Second Grade Students of MA Futuhiyyah 2 Demak)}

\author{
Siti Kholifah ${ }^{1}$, Mursid Saleh ${ }^{2}$, Abdurrachman Faridi ${ }^{3}$ \\ ${ }^{1}$ Student of English Department of semarang State University, Indonesia \\ ${ }^{2}$ Lecture of English education Department of State University Semarang, Indonesia \\ ${ }^{3}$ Lecture of English education Department of State University Semarang, Indonesia
}

DOI: 10.29322/IJSRP.11.10.2021.p11824

http://dx.doi.org/10.29322/IJSRP.11.10.2021.p11824

\begin{abstract}
The objectives of the study is as follows to know the students' intrinsic motivation in speaking English Skill, a case of the second grade of MA Futuhiyyah 2 Demak in the Academic Year of 2020/2021, to know the speaking skill is a case study of the second grade of MA Futuhiyyah 2 demak in the academic year of 2020/2021, to describe the effect of the students' intrinsic motivation to improve English speaking skill, a case of the second grade of MA Futuhiyyah 2 demak in the academic year of 2020/2021.The method in this research was descriptive quantitative method. The population of this research is the eleventh grade students of MA Futuhiyyah 2 Demak in the academic year 2020/2021. The sampling in this research is purposive sampling. Technique of the collecting data are questionnaire and speaking' test. Technique of the data analysis used correlation and t test. The result of the mean of the students' intrinsic motivation is 83,93 . The mean of students' speaking score is 88 . The effect of Students' Intrinsic Motivation to improve Speaking Skill. The result of $t$ test is 2,30. From Df $=28$, it is obtained $t_{\text {table }}=2,048$. It means that $t_{\text {count }}$ is bigger than $t_{\text {table }}$ or 2,30 $>2,048$. Therefore the alternative hypothesis is accepted. In other words, there is any effect of the students' intrinsic motivation to improve English speaking skill, a case of the second grade students of MA Futuhiyyah 2 Demak in the academic year of 2020/2021.
\end{abstract}

Index Terms- Intrinsic Motivation, English Campetence, Speaking Skill

\section{INTRODUCTION}

$\mathrm{M}$ otivation is an essential factor in the students learning process. The success of the students studying process is depending on their motivation. Motivation leads them to reach their goals. As Ormrod (2011:362) says, "It leads to increase the effort and energy in pursuit of those goals". Therefore, motivation is the key to open their future success. Motivation has an important role to influence the power of learning activity, but the motivation is also influenced by the goals. If there is a higher goal, there is a bigger motivation to reach the goal. Motivation also have functions to a ctivate and increase the activity as an effort to reach the goals. As Harmer (2001), says that motivation is some kind of internal drive which pushes somes someone to do things in order to achieve something. "Motivation also can functioned to activate and increase the activity". If the students have a good motivation, they will more enthusiastic in the studying process and surely they will get a better result than the students without motivation. There are two base motivations that have correlation with students learning process, intrinsic motivation and extrinsic motivation. Motivation is one of the important factors that influence individuals' levels of success in any activities. Motivation could be fineded as a power that involves descire, effort and enjoyment which gives someone energy to do something or move toward an end or goal. According to (Pamujo Effa Kusdianang, 2016), motivations play important role for students to achieve their goal in learning. In the process of learning, motivation can be said as an inner drive to achieve learning activity so the purpose of the subject learning can be maintained in educational environment, motivation is one of the very important factors to encaourage a learner to learn more rapidly and effectively. According to (Putri Marinda Yulis, Rivi Antoni 2019) the motivation may come from the learners themselves that is the intrinsic, or outside of the learners, that is, the extrinsic. For those who have intrinsic motivation, they will have strong responsibility to learn. On the contrary, for those who have extrinsic motivation, their enthusiasm to study depends on the conditions outside outside themselves.

Interest that including in the intrinsic motivation, have a big effect in the students learning process. Feeling enjoy only happens when the students have an interest in the program which they really want to choose. If the students do not feel enjoy the class, the material taught is difficult to be transferred. Students who are interested in a particular topic or program, will give more attention to it and become more engage in the material. According to (Widayanti et al., 2020) "motivasion is one of important factors to encourage people to do something more rapidly and effectively. Motivation states that motivation as internal state that arouses someone to act pushes someone in particular directions, and keeps 
engaged in certain activites. It means that motivation has a crucial role in everything we will door someone's activities". It means that motivation will make teaching and learning process be come easier. It is very good for both teacher and students to motivate each other in teaching and learning process. They will feel like trapped in the hurting world which they never imagine before. It is really possible if the uninterested students who forced to sustain their studying load will fail in their study, because they do not have motivation to defense themselves in the hard situation of learning process. They do not have a willing to understand something they never expect. Unluckily it becomes the core problem which makes them give up before they finish their study. Surely it is a terrible situation for their future life success. In this case, uninterested students are also found in English Department of Muhammadiyah University of Ponorogo. The researcher met many of her classmates who do not have an interest in English Department. As many people know that studying in the university will give a big effect for students' future, because it will affect their career in the work life. The challenge is the students know English as a foreign language, so it is not a simple duty to make them easy in learning English. It needs high skill and the mature principle to make them successful distributes their knowledge to the students in the future life. Surely it is not a light problem to become a good teacher, needs hard effort and strong desire to build the motivation to make them success in their study and reach their goal as an English teacher. Therefore, it sounds so strange and so impossible if the students who do not have interest in English class can survive themselves, get a good result and the farthest is finishing their study, but in fact many of her classmates who do not have interest in English class can defense themselves until the highest level of their study. It is really unpredictable, because some of them become a prominent student in the class. It becomes an interesting problem for the researcher about her classmates' motivation in their study sustainability.

Motivation is also very important factor which determines the success or failure in language learning because motivation can directly affect the frequency of use of learning strategies, willingness to learn, goal setting and achievement in learning. The relationship between motivation and achievement is indirect, because achievement also influenced of other factors most notably by, the learners' ability, learning opportunities, the instructional quality of the learning tasks. speaking.

Actually all of student have different motivation in learning

Another definition by Brown (2004: 140) speaking is a productive skill that can be directly and empirically observed, those observations are invariably colored by the accuracy and effectiveness of a test taker's listening skill, which necessarily compromises that reliability and validity of an oral production test. Meanwhile, according to Kayi (2011: 161) defines that speaking is the process of building and sharing meaning through the use of verbal and non-verbal symbols in variety of context.

According Harmer (2009) speaking is rehearsal opportunities-chances to practice real-life speaking in the safety of the classroom. From the definition above, speaking is the daily activity in the classroom. Teacher always practice speaking activity to deliver the message. According to Harmer (2003) speaking is the ability to speak fluently presupposes not only a knowledge of language features, but also the ability to process information and language 'on the spot'.

The second grade students of MA Futuhiyyah 2 Demak,often find some problems in learning speaking skill. Students some times get lost in their opinion. In speaking activity, the students have some problems to improve in discussion. They can not speak in public. The students think of ideas and the language to express them with before being asked to talk in front of the class slowly, the stress level of that eventual whole-class performance is not clear. The students can apply their speaking skill in daily activity. So, they can not improve their speaking skill. According to (Maulana, Wahyuni, and Siregar, 2019) speaking is important to be mastered by people if they want to get a lot of informations. Another research from Wa Ode Fatimah, Firdaus Sale, (2019) motivation is one the main aspects that make students interesting in speaking English in order to achieve goals in EFL learning. English speaking is very needed to master in this era because almost countries in the world use English as an effective tool of international communication (Yevi elok Fortuna, Elih Sutisna Yanto 2020).

Based on the explanation above, the researcher is interested in using students' motivatin in teaching speaking. The research will conduct the research entitled "The Effect of Intrinsic Motivation on Students' Improvement of English Speaking Skill”.

\section{RESEARCH AND COLLECTING IDEA}

The method in this research was descriptive quantitative method. The population of this research is the eleventh grade students of MA Futuhiyyah 2 Demak in the academic year 2020/2021. The sampling in this research is purposive sampling. Technique of collecting data are questionnaire and speaking' test. Technique of the data analysis used correlation and t test.

\section{FINDINGS AND DISCUSSIONS}

The aim of this study is to find out intrinsic motivation the case of the second grade students of MA Futuhiyyah 2 Demak in the academic year 2020/2021.

The following is the list of the level of achievement that shows the percentage of the correct answers and the second grade students of for the first year students of MA Futuhiyyah 2 Demak in the academic year 2020/2021.

\section{Students' Intrinsic Motivation.}

\section{a. Score of questionnaire}

As mentioned in technique of data analysis, the questionnaires in this study have 50 items. Before the questionnaires were distributed, the questionnaire were validated by rxy product moment. It means that questionnaires were used content validity o see they are measure what should to be measured.

The following table describes the result of questionnaires about students' motivation in learning speaking after accumulated. 
Table 1.Score of Students' Intrinsic Motivation in Learning Speaking (X Variable)

\begin{tabular}{|c|c|c|}
\hline Number & Sum & Criteria \\
\hline 1. & 215 & Excellent \\
\hline 2. & 211 & Excellent \\
\hline 3. & 215 & Excellent \\
\hline 4. & 207 & Good \\
\hline 5. & 204 & Good \\
\hline 6. & 208 & Excellent \\
\hline 7. & 195 & Good \\
\hline 8. & 210 & Excellent \\
\hline 9. & 211 & Excellent \\
\hline 10. & 205 & Good \\
\hline 11. & 211 & Excellent \\
\hline 12. & 217 & Excellent \\
\hline 13. & 217 & Excellent \\
\hline 14. & 205 & Good \\
\hline 15. & 214 & Excellent \\
\hline 16. & 210 & Excellent \\
\hline 17. & 221 & Excellent \\
\hline 18. & 219 & Excellent \\
\hline 19. & 218 & Excellent \\
\hline 20. & 214 & Excellent \\
\hline 21. & 226 & Excellent \\
\hline 22. & 207 & Good \\
\hline 23. & 187 & Good \\
\hline 24. & 195 & Good \\
\hline 25. & 210 & Excellent \\
\hline 26. & 217 & Excellent \\
\hline 27. & 208 & Excellent \\
\hline 28. & 210 & Excellent \\
\hline 29. & 196 & Good \\
\hline 30. & 212 & Excellent \\
\hline
\end{tabular}

From the table above, it can be seen that the distribution of students' score. The list of students' standard scores of students' intrinsic motivation can be represented by the following table of distribution.
Table 2. Distribution of the Students' Motivation

\begin{tabular}{|l|l|l|l|}
\hline Score & $\begin{array}{l}\text { Level of } \\
\text { Students } \\
\text { Motivation }\end{array}$ & $\begin{array}{l}\text { Percentag } \\
\text { e }\end{array}$ & Frequency \\
\hline $50-89$ & Low & & \\
$90-129$ & $\begin{array}{l}\text { Farly } \\
\text { sufficient }\end{array}$ & & \\
\hline $\begin{array}{l}130- \\
169\end{array}$ & Sufficient & & \\
\hline $\begin{array}{l}170- \\
209\end{array}$ & Good & $30 \%$ & 9 \\
\hline $210-$ & Excellent & $70 \%$ & 21 \\
250 & & & \\
\hline
\end{tabular}

\section{Intrinsic Motivation}

It is clearly seen in the table above that out of 30 students' only 9 students or $30 \%$ of from were good' motivation, 21 students or $70 \%$ in the level of excellent' motivation.

The mean of students' intrinsic motivation the mean of students' intrinsic motivation, it can be seen from the table above:

Table 3. Intrinsic Motivation

\begin{tabular}{|c|c|c|}
\hline \\
\hline & & Intrinsic Motivation \\
\hline & Valid & 30 \\
\hline & Missing & 0 \\
\hline \multicolumn{2}{|c|}{ Mean } & 83.93 \\
\hline \multicolumn{2}{|c|}{ Median } & 84.20 \\
\hline \multicolumn{2}{|c|}{ Mode } & 84 \\
\hline \multicolumn{2}{|c|}{ Std. Deviation } & 3.358 \\
\hline \multicolumn{2}{|c|}{ Range } & 16 \\
\hline \multicolumn{2}{|c|}{ Minimum } & 75 \\
\hline \multicolumn{2}{|c|}{ Maximum } & 90 \\
\hline
\end{tabular}

From the result above, it can be seen that mean of the students' intrinsic motivation are 83,93 . The median is 84,20 , the mode is 84 . The range is 16 , the minimum score of students' intrinsic motivation is 75 and the maximum score of students' intrinsic motivation is 90 .

\section{Students' Speaking Skill}

In this case, the students' speaking ability is as the dependent variable (Y). To know the students' speaking score, the researcher conducted oral test to the students. The test is evaluated into five criteria, they are pronounciation, grammar, vocabulary, fluency and comprehension. The five criteria are the components of speaking skill. In this study, the students are scored based on 
five components of speaking skill by using the scale rating score. Here are the results of students' speaking ability.

Table 4. Score of Students' Speaking Test (Y Variable)

\begin{tabular}{|c|c|c|}
\hline No. & Resp. & $\mathrm{Y}$ \\
\hline 1 & Adenia Sarah Mutiara & 88 \\
\hline 2 & $\begin{array}{l}\text { Ahmad Luthfi Luqman } \\
\text { Hakim }\end{array}$ & 88 \\
\hline 3 & Alfi Choirun Nisa & 84 \\
\hline 4 & Allam Khoirun Na`Im & 80 \\
\hline 5 & Ana Maesaroh & 80 \\
\hline 6 & Ayu Pembayun & 84 \\
\hline 7 & Dela Febriyanti & 88 \\
\hline 8 & Eka Imania Mahira & 88 \\
\hline 9 & Fadhila Nurul Mukharomah & 88 \\
\hline 10 & Faiza Miftakhush Shofa & 88 \\
\hline 11 & $\begin{array}{lll}\text { Fatchia } & \text { Auliana } & \text { Lailatul } \\
\text { Chasani } & & \\
\end{array}$ & 84 \\
\hline 12 & Ita Nur Hidayatul Uluwiyah & 92 \\
\hline 13 & $\begin{array}{lll}\text { Kholifah } & \text { Tiyas } & \text { Sahid } \\
\text { Nurjanah } & & \\
\end{array}$ & 88 \\
\hline 14 & Lazimatul Ainur Rofiah & 80 \\
\hline 15 & Linda Yuliana Rahmawati & 88 \\
\hline 16 & Malikul Mulky Alamsyah & 88 \\
\hline 17 & Maulidatul Ulya Falasifah & 84 \\
\hline 18 & Milda Fitria Salsabila & 96 \\
\hline 19 & $\begin{array}{l}\text { Milha Anjum Shofiyana } \\
\text { Hifshoh }\end{array}$ & 88 \\
\hline 20 & Muhammad Najiy Yullah & 88 \\
\hline 21 & Muhammad Qurunul Bahri & 96 \\
\hline 22 & Muhammad Zubair Prakosa & 84 \\
\hline 23 & Nafisatut Tazkiyyah & 84 \\
\hline 24 & Nurun Nazila & 80 \\
\hline 25 & Putri Eka Erviana & 88 \\
\hline 26 & Qina Salama & 76 \\
\hline 27 & Rizka Nadiyah & 88 \\
\hline 28 & Salwa Kamila & 84 \\
\hline 29 & Seli Rahmatika & 88 \\
\hline \multirow[t]{3}{*}{30} & Tarva Elsa Khoirun Nisya & 84 \\
\hline & Sum & 2584 \\
\hline & Mean & 86.13333 \\
\hline
\end{tabular}

The list of the students speaking score can be represented by the following table distribution.

Table 5. The Students Speaking Score

\begin{tabular}{|l|l|l|l|}
\hline $\begin{array}{l}\text { Range of } \\
\text { score }\end{array}$ & $\begin{array}{l}\text { Frequenc } \\
\mathrm{y}\end{array}$ & $\begin{array}{l}\text { Percenta } \\
\text { ge }\end{array}$ & $\begin{array}{l}\text { Level of } \\
\text { achieveme } \\
\text { nt }\end{array}$ \\
\hline $91-100$ & 3 & 10 & Very good \\
\hline $81-90$ & 21 & 70 & Good \\
\hline $71-80$ & 6 & 20 & Sufficient \\
\hline $60-70$ & & & Poor \\
\hline$<60$ & & & Bad \\
\hline
\end{tabular}




\begin{tabular}{|c|c|c|c|c|c|c|}
\hline 5 & $\begin{array}{l}\text { Ana } \\
\text { Maesaro } \\
\mathrm{h} \\
\end{array}$ & 81.6 & 80 & $\begin{array}{l}6658 . \\
56 \\
\end{array}$ & 6400 & 6528 \\
\hline 6 & $\begin{array}{l}\text { Ayu } \\
\text { Pembayu } \\
\text { n }\end{array}$ & 83.2 & 84 & $\begin{array}{l}6922 . \\
24\end{array}$ & 7056 & $\begin{array}{l}6988 . \\
8\end{array}$ \\
\hline 7 & $\begin{array}{l}\text { Dela } \\
\text { Febriyan } \\
\text { ti }\end{array}$ & 78 & 88 & 6084 & 7744 & 6864 \\
\hline 8 & $\begin{array}{l}\text { Eka } \\
\text { Imania } \\
\text { Mahira }\end{array}$ & 84 & 88 & 7056 & 7744 & 7392 \\
\hline 9 & $\begin{array}{l}\text { Fadhila } \\
\text { Nurul } \\
\text { Mukharo } \\
\text { mah }\end{array}$ & 84.4 & 88 & $\begin{array}{l}7123 . \\
36\end{array}$ & 7744 & $\begin{array}{l}7427 . \\
2\end{array}$ \\
\hline 10 & $\begin{array}{l}\text { Faiza } \\
\text { Miftakhu } \\
\text { sh Shofa }\end{array}$ & 82 & 88 & 6724 & 7744 & 7216 \\
\hline 11 & $\begin{array}{l}\text { Fatchia } \\
\text { Auliana } \\
\text { Lailatul } \\
\text { C }\end{array}$ & 84.4 & 84 & $\begin{array}{l}7123 . \\
36\end{array}$ & 7056 & $\begin{array}{l}7089 . \\
6\end{array}$ \\
\hline 12 & $\begin{array}{l}\text { Ita Nur } \\
\text { Hidayatu } \\
\text { l } \\
\text { Uluwiya } \\
\text { h }\end{array}$ & 86.8 & 92 & $\begin{array}{l}7534 . \\
24\end{array}$ & 8464 & $\begin{array}{l}7985 . \\
6\end{array}$ \\
\hline 13 & $\begin{array}{l}\text { Kholifah } \\
\text { Tiyas } \\
\text { Sahid } \\
\text { Nurjanah }\end{array}$ & 86.8 & 88 & $\begin{array}{l}7534 . \\
24 \\
\end{array}$ & 7744 & $\begin{array}{l}7638 . \\
4\end{array}$ \\
\hline 14 & $\begin{array}{l}\text { Lazimatu } \\
1 \text { Ainur } \\
\text { Rofiah }\end{array}$ & 82 & 80 & 6724 & 6400 & 6560 \\
\hline 15 & $\begin{array}{l}\text { Linda } \\
\text { Yuliana } \\
\text { Rahmaw } \\
\text { ati } \\
\end{array}$ & 85.6 & 88 & $\begin{array}{l}7327 . \\
36\end{array}$ & 7744 & $\begin{array}{l}7532 . \\
8\end{array}$ \\
\hline 16 & $\begin{array}{l}\text { Malikul } \\
\text { Mulky } \\
\text { Alamsya } \\
\text { h }\end{array}$ & 84 & 88 & 7056 & 7744 & 7392 \\
\hline 17 & $\begin{array}{l}\text { Maulidat } \\
\text { ul Ulya } \\
\text { Falasifah }\end{array}$ & 88.4 & 84 & $\begin{array}{l}7814 . \\
56\end{array}$ & 7056 & $\begin{array}{l}7425 . \\
6\end{array}$ \\
\hline 18 & $\begin{array}{l}\text { Milda } \\
\text { Fitria } \\
\text { Salsabila } \\
\end{array}$ & 87.6 & 96 & $\begin{array}{l}7673 . \\
76\end{array}$ & 9216 & $\begin{array}{l}8409 . \\
6 \\
\end{array}$ \\
\hline 19 & $\begin{array}{l}\text { Milha } \\
\text { Anjum } \\
\text { Shofiyan } \\
\text { a H }\end{array}$ & 87.2 & 88 & $\begin{array}{l}7603 . \\
84\end{array}$ & 7744 & $\begin{array}{l}7673 . \\
6\end{array}$ \\
\hline 20 & $\begin{array}{l}\text { Muham } \\
\text { mad } \\
\text { Najiy } \\
\text { Yullah }\end{array}$ & 85.6 & 88 & $\begin{array}{l}7327 . \\
36\end{array}$ & 7744 & $\begin{array}{l}7532 . \\
8\end{array}$ \\
\hline
\end{tabular}

\begin{tabular}{|c|c|c|c|c|c|c|}
\hline 21 & $\begin{array}{l}\text { Muham } \\
\text { mad } \\
\text { Qurunul } \\
\text { Bahri }\end{array}$ & 90.4 & 96 & $\begin{array}{l}8172 . \\
16\end{array}$ & 9216 & $\begin{array}{l}8678 . \\
4\end{array}$ \\
\hline 22 & $\begin{array}{l}\text { Muham } \\
\text { mad } \\
\text { Zubair } \\
\text { Prakosa }\end{array}$ & 82.8 & 84 & $\begin{array}{l}6855 . \\
84\end{array}$ & 7056 & $\begin{array}{l}6955 . \\
2\end{array}$ \\
\hline 23 & $\begin{array}{l}\text { Nafisatut } \\
\text { Tazkiyya } \\
\text { h }\end{array}$ & 74.8 & 84 & $\begin{array}{l}5595 . \\
04\end{array}$ & 7056 & $\begin{array}{l}6283 . \\
2\end{array}$ \\
\hline 24 & $\begin{array}{l}\text { Nurun } \\
\text { Nazila }\end{array}$ & 78 & 80 & 6084 & 6400 & 6240 \\
\hline 25 & $\begin{array}{l}\text { Putri Eka } \\
\text { Erviana }\end{array}$ & 84 & 88 & 7056 & 7744 & 7392 \\
\hline 26 & $\begin{array}{l}\text { Qina } \\
\text { Salama }\end{array}$ & 86.8 & 76 & $\begin{array}{l}7534 . \\
24\end{array}$ & 5776 & $\begin{array}{l}6596 . \\
8\end{array}$ \\
\hline 27 & $\begin{array}{l}\text { Rizka } \\
\text { Nadiyah }\end{array}$ & 83.2 & 88 & $\begin{array}{l}6922 . \\
24\end{array}$ & 7744 & $\begin{array}{l}7321 . \\
6\end{array}$ \\
\hline 28 & $\begin{array}{l}\text { Salwa } \\
\text { Kamila }\end{array}$ & 84 & 84 & 7056 & 7056 & 7056 \\
\hline 29 & $\begin{array}{l}\text { Seli } \\
\text { Rahmati } \\
\text { ka }\end{array}$ & 78.4 & 88 & $\begin{array}{l}6146 . \\
56\end{array}$ & 7744 & $\begin{array}{l}6899 . \\
2\end{array}$ \\
\hline 30 & $\begin{array}{l}\text { Tarva } \\
\text { Elsa } \\
\text { Khoirun } \\
\text { Nisya }\end{array}$ & 84.8 & 84 & $\begin{array}{l}7191 . \\
04\end{array}$ & 7056 & $\begin{array}{l}7123 . \\
2\end{array}$ \\
\hline & Sum & 2518 & 2584 & $\begin{array}{l}21167 \\
1.2\end{array}$ & $\begin{array}{l}22313 \\
6\end{array}$ & $\begin{array}{l}21704 \\
4.8\end{array}$ \\
\hline & Mean & $\begin{array}{l}83.93 \\
333\end{array}$ & $\begin{array}{l}86.13 \\
333\end{array}$ & $\begin{array}{l}7055 . \\
707\end{array}$ & $\begin{array}{l}7437 . \\
867\end{array}$ & $\begin{array}{l}7234 . \\
827\end{array}$ \\
\hline
\end{tabular}

The values above, then, there are put into the Pearson's Product moment correlation formula as follows:

$$
r_{x y}=\frac{N \sum X Y-\left(\sum X\right)\left(\sum Y\right)}{\sqrt{\left\{N \sum X^{2}-\left(\sum X\right)^{2}\right\}-\left\{N \sum Y^{2}-\left(\sum Y\right)^{2}\right\}}}
$$

If the $r_{\text {value }}>r_{\text {table }}$, so the hypothesis is accepted. From that result, it means that there is correlation between the students' intrinsic motivation between the students' speaking skill.

From the calculation above, it is found that $\mathrm{r}_{\mathrm{XY}}$ is 0,374 . The next step is to find out the significance of variable by calculating $r_{X Y}$ is tested by significance test formula.

$$
\begin{aligned}
& \quad \frac{r \sqrt{n-2}}{\sqrt{1-r 2}} \\
& t_{\text {count }}= \\
& \text { In which: } \\
& t \text { count } \\
& r \quad t_{\text {value }} \\
& r \quad=\text { value of correlation coefficient } \\
& n \quad=\text { total of sample }
\end{aligned}
$$

Therefore, it is calculated that:

$$
=\frac{\mathrm{r} \sqrt{\mathrm{n}-2}}{\sqrt{1-\mathrm{r} 2}}
$$




\section{$=2,300857$}

Before tested by $\mathrm{t}_{\text {count, }}$ the writer made two hypothesis of significance as an alternative hypothesis ( $\mathrm{Ha}$ ) and a null hypothesis (Ho).

Ha : $\quad$ There is any effect of the students' intrinsict motivation to improve speaking skill a case of the second grade student of MA Futuhiyyah 2 Demak in the academic year of 2020/2021.

Ho : $\quad$ There is no effect of the students' intrinsict motivation to improve speaking skill a case of the second grade student of MA Futuhiyyah 2 Demak in the academic year of 2020/2021.

\section{The formulation of test:}

1. If $t_{\text {count }}>t_{\text {table }}$, it means that nul hypothesis is rejected and there is any effect.

2. If $t_{\text {count }}<t_{\text {table }}$, it means that nul hypothesis is rejected and there is no effect.

Based on the calculation above, the result is compared by $t_{\text {table }}$ in the significant 0,005 and $n=30$. The writer found out the Degree of Freedom (Df) with the formula:

$$
\text { Df } \quad \begin{aligned}
& =\mathrm{N}-\mathrm{n} \\
& =30-2 \\
& =28
\end{aligned}
$$

From $\mathrm{Df}=28$, it is obtained $\mathrm{t}_{\text {table }}=2,048$. It means that $\mathrm{t}_{\text {count }}$ is bigger than $t_{\text {table }}$ or $2,30>2,048$. Therefore the alternative hypothesis is accepted. In other words, there is any effect of the students' intrinsic motivation to improve speaking skill a case of the second grade student of MA Futuhiyyah 2 Demak in the academic year of 2020/2021.

\section{CONCLUSION}

The purpose of this research was to determine the effect of intrinsic motivation to improve speaking ability. The researcher was conducted to answer the questions is there is any effect between intrinsic motivation and speaking skill by giving questionnaire of motivation and speaking test conducted at English students association. The researcher found several findings.

\section{The Students' Intrinsic Motivation, a case of the second grade student $\mathbf{2 0 2 0 / 2 0 2 1}$}

The first, the students' intrinsic motivation are 30 students' only 9 students or $30 \%$ of from were good' motivation, 21 students or $70 \%$ in the level of excellent' motivation. The mean of the students' intrinsic motivation are 83,93 . The median is 84,20 , the mode is 84 . The range is 16 , the minimum score of students' intrinsic motivation is 75 and the maximum score of students' intrinsic motivation is 90 .

Based on the students answer on questionnaire, the researcher found that most of students have good intrinsic motivation. It can be seen from indicator students' intrinsic questionnaire. The questionnaire consists of learning motivation, achievement motivation, creative motivation and physiological motivation. The student got the good score in the intrinsic motivation. The students' motivation has a very important role to make students gain success in learning English. It is an urgent variable to be considered by teacher in recognizing the students' problem and to create conducive atmosphere in the classroom that will raise the students to do more toward learning English. By having the great motivation, the learners are able to respond to the learning situation, seek out all opportunities to acquire English language, make maximum use of the opportunities afforded to practice the language, posses' analytic skill, be adaptable in teach situation posses, self esteem and take a risk for their learning. According to Uno (2009) affirmed the roles of motivation in learning, such as motivation learning reinforcement, motivation makes learning objectives clearer and motivation makes learning persistent. Further, Menggo (2018) revealed that motivation is an important factor in effort. It is as a positive energy, and practical direction for all aspect of activation in supporting learning activities, attends to the tasks, show desire to achieve the goal, enjoys the activities, and the like obviously can not be separated by their English learning motivation. While, (Afprimaita, 2018) motivation is also one of the factors that influence many people to learn the language. Because the motivated individual is the person who wants to achieve a certain goal, devote enough effort to achieve that goal, and experience satisfaction in the activities associated with achieving that goal.

As we can see that motivation is important for students but not influence a lot of speaking, students who have a higher motivation also can speak fluently among they who do not have it. It means that motivation is important for them who want to learn especially in speaking. They need to put their motivation in their life because it recognizes them as their own abilities. As we can see students who have a motivation, they also have an optimist to do something. Moreover, they can be active especially in learning activities. Teacher is the one who can lead students to get a motivation at school.

Based on the theory, motivation is very important in everything we will do. It is a powerful for us to get the best in doing something. Moreover, in teaching and learning process, motivation is really needed. Motivation makes teaching and learning easier and more interesting. It is very good if both of teacher and students motivate each other in teaching and learning process, especially in speaking. Speaking is an active activity which is used by a person to exchange ideas, information, opinions and emotion to other persona. Speaking is also the way of communication influences, agreements, ideas, feelings, wishes, and argumentations by symbols called words that form into statement (Afprimaita 2018).

Basically motivation greatly (Afprimaita, 2018) effect students speaking skill. The reason that students have is higher motivation, so their learning outcomes and speaking skill will be better. According to motivation is also one of the factors that influence many people to learn the language. Because the motivated individual is the person who wants to achieve a certain goal, and students must have the motivation to learn to improve their speaking ability in English communication.

\section{The Students Speaking Skill, A Case of The Second Grade Student 2020/2021}

The result of students' speaking skill are 10 students or $10 \%$ in the level very good, 21 students or $70 \%$ in the level of good, 6 students or $20 \%$ in the level sufficient. The mean of students' speaking score is 86,13 . The median of students' speaking score is 88 , the mode of students' speaking score is 88 , the standard deviation of students' speaking score is 4,424 , the 
range of students' speaking score is 20 , the minimum score of students' speaking is 76 , and the maximum score of students speaking is 96 .

From the score above, it can be said that the students' speaking skill of the second grade students of MA Futukhiyah 2 is good. Speaking is very important in English class. Speaking is also tool of communication for students to communicate with teachers and classmates. Using speaking, teacher can convey what they do not understand about learning. This is why the speaking skills are needed partner in the learning process. As an active skill, speaking is also very difficult to be taught to students in the classroom for English. Because in English speaking class the students are hoped to speak and also demanded to share ideas, interact each other and communicate in English. Then, the students face problems in their ideas. In this case, students tend to listen, and they do not enthusiast to speak English in the classroom.

In addition as previous study, (Husna 2021) speaking English is considered the most important skill to master because English is an a strong position as an international language in communication. While, Meriana (2021) speaking ability is one of the language skills that everyone needs to have. To have the ability to speak is not as easy as everyone imagines. And the ability to speak is not an ability that is passed down from generation to generation, or naturally humans can speak. Formal speaking skills require practice and effective direction or guidance.

A previous study from Sunaidah, Simaibang, and Mulyadi (2021) there is any correlation between learning motivation and speaking ability. In learning, motivation plays a critical role in building students self-competencies that allow them make efforts to achieve their goals. They will learn more so that their English gets better and, especially in speaking, they will be able to specify their opinion in the target language.

\section{The Effect of Students' Intrinsic Motivation to improve Speaking Skill}

The effect of students' intrinsic motivation to improve speaking ability, it can be seen from the result of the t test. In the $\mathrm{t}$ test, it can be found the result that $\mathrm{t}$ value is 2,30 . After that, from $\mathrm{df}=\mathrm{N}-1=29$, it is obtained $\mathrm{t}_{\text {table }}=2,04$. It means that $\mathrm{t}_{\text {count }}$ is bigger than $t_{\text {table }}$ or $2,30>2,04$. Therefore the alternative hypothesis is accepted. In other words, there is any effect of the students' intrinsic motivation to improve speaking skill a case of the second grade student of MA Futuhiyyah 2 Demak in the academic year of 2020/2021.

Dealing with the correlation value between the motivation and speaking ability, this research found that there was a correlation. The result of computation was 0,374 . This value is categorized into high correlation based on Sugiyono (2017). Thus, the alternative hypothesis (Ha) is accepted. From the data motivation and speaking skill of the second year students of the students' intrinsic motivation to improve speaking skill a case of the second grade student of MA Futuhiyyah 2 Demak in the academic year of 2020/2021.

Teacher should support their learners to figure out the motivation and alos to search for their own motivational process. According to (Pratama and Fridolini, 2021) that intrinsic motivation in language learning refers to motivatation to involve in an activity because the activity is enjoyable and interesting to take part.
According to Putra et al. (2017) 2017) motivate behavior is important give in the classroom and learning process, especially in speaking learning process in every meet in the classroom, include some dimension, positive task orientation, ego involvement, need for achievement high aspirations, goal orientation, perseverance and tolerance of ambiguity. While (Harmer, 1991) stated that motivation an energy that can encourage student to do something both coming from inside or from outside. In terms of speaking, motivation will provide strength for student to learn speaking. As for motivate students, they will do anything to support their performance. They will do their best to achieve the best results. According to Ritonga, Nasmilah, and Rahman (2020) the research result showed that the impact of motivation on learners was positives. This was by structured organization in their deliveries, their interest and ability to perform well. The speaking presentation gained the appreciation of both the audience and the teacher. In addition as previous study, Apriliyanti, Mujiyanto (2018) this result showed that students with high interest in English will prepare anything before performing. They prepared for the script, mentality and also their expression. This reason is because they were influenced by the use of score categorization that had been delivered to the students in the form of speaking English performing instruction.

\section{REFERENCES}

[1] Afprimaita, Riza. 2018. "The Correlati on between Students' Motivation and Speaking Ability at Sma n 2 Padang in Academic Year 2017/2018."

[2] Apriliyanti, Retno, Januarius Mujiyanto, and Stikes Karya Husada Semarang. 2018. "English Education Journal The Correlation Between Interest, Motivation, English Self-Concept and English Speaking Performance in Nursing $\quad$ Students.” $\quad$ Eej $\quad 8(2)$ : $138-47$ http://journal.unnes.ac.id/sju/index.php/eej.

[3] Harmer. 1991. The Practice of English Language Teaching.

[4] Harmer, Jeremy. 2003. How to Teach English. New York: Longman.

[5] 2009. How to Teach English. England: Longman.

[6] Husna, Hawa Asma U1. 2021. "The Relationship between the Students" English Speaking Skills and Their Closeness to English.” Language Circle: Journal of Language and Literature 15(2): 229-40.

[7] Maulana, Diki, Widya Sri Wahyuni, and Detya Siregar. 2019. "The Correlation Between Motivation Behaviour and Speaking Ability." PROJECT (Professional Journal of English Education) 1(2): 115.

[8] Menggo, Sebastianus. 2018. "English Learning Motivation and Speaking Ability." Journal of Psychology and Instructions 2(2): 70.

[9] Pamujo Effa Kusdianang, Dwi Anggani LIinggar Bharati. 2016. "Improving Students ' Motivation in Speaking Ability By." English Education Journal 6(2): 1-9.

[10] Pratama, Yoga, and Fridolini Fridolini. 2021. "The Influence of Native English Lecturer in Improving Students Motivation in Communication Skill." Getsempena English Education Journal 8(1): 192-204.

[11] Putra, Aidil Syah et al. 2017. "The Correlation Between Motivation And." Journal of English Language Education and Literature II(1): 36-57.

[12] Putri Marinda Yulis, Rivi Antoni, Ummi Rasyidah. 2019. "The Correlation Between Students Motivation and Their Speaking Skill at MAN 2 Padang." Jurnal Ilmiah Pendidikan Scholastic 3(3): 52-57.

[13] Ritonga, Sitti Nur Aisyah, Nasmilah Nasmilah, and Fathu Rahman. 2020 "The Effect Of Motivation And Anxiety On Students' Speaking Performance: A Study At Dayanu Ikhsanuddin University." ELS Journal on Interdisciplinary Studies in Humanities 3(2): 198-213.

[14] Sunaidah, Sunaidah, Baginda Simaibang, and Mulyadi Mulyadi. 2021 "Correlation among Students Learning Styles, Learning Motivation and the Eleventh Grade Students ' Speaking Ability.” 6(2): 598-603.

[15] Wa Ode Fatimah, Firdaus Sale, Yulius Tandi Sapan. 2019. "The Correlation between Students' Motivation and Their Speaking Achievement at English 
Department of Halu Oleo University." Paper Knowledge . Toward a Media History of Documents 3(2): 249-59.

[16] Widayanti, Aning et al. 2020. "The Correlation Between Students' Motivation and Their Speaking Ability." 434(Iconelt 2019): 153-60.

[17] Yevi elok Fortuna, Elih Sutisna Yanto, Fauzi Miftakh. 2020. "Vocational Students' Engangement in Enhancing Students' Speaking Skill." International Journa $\mathrm{L}$ of Education, Information Technology and Others (Ijeit) 2(1): 278-85.

\section{AUTHORS}

First Author - Siti Kholifah, Student of English Department of semarang State University, Indonesia

Second Author - Mursid Saleh, Lecture of English education Department of State University Semarang, Indonesi

Third Author - Abdurrachman Faridi, Lecture of English education Department of State University Semarang, Indonesia

Corresponding e-mail: sitikholifahdemak81@gmail.com 